\title{
ANALISA PRODUK CACAT MENGGUNAKAN METODE PETA KENDALI P DAN ROOT CAUSE ANALYSIS
}

\author{
Hartami Dewi $^{(1)}$, Maryam $^{(1)}$, Didik Sutiyarno ${ }^{(2)}$ \\ (1) Teknik Industri Agro, Politeknik ATI Padang \\ (2) Teknik Industri, Institut Sains dan Teknologi Al Kamal
}

\section{hartamidewi@gmail.com}

\begin{abstract}
Abstrak
Revolusi Industri 4.0 mempengaruhi cara produksi industri untuk lebih memperhatikan efektivitas dan tingkat produksi efisiensi. Produk cacat terjadi karena produk tidak memenuhi standar dan menunjukkan ketidakefisienan proses produksi. Tingginya produsk cacat akan meningkatkan biaya proses produksi yang akan mengurangi keuntungan perusahaan. Data produksi dari Agustus hingga September 2017 pada PT. XYZ menunjukkan peningkatan produk cacat dan berdasarkan data produksi untuk 5 line yang beroperasi, diketahui bahwa produk dengan produk cacat tertinggi adalah line 2 pada bulan september yaitu sebanyak 398 produk cacat dari 3120 produk sampling. Analisis Peta Kendali P menunjukkan bahwa produk yang ditolak masih terkendali. Berdasarkan Root Cause Analysis (RCA) diketahui bahwa penyebab tingginya produk cacat pada line 2 di bulan September adalah bahan baku yang sudah lama dan kurangnya perawatan mesin produksi sehinga kinerja mesin tidak maksimal. Bberdasarkan hasil analisis diketahui bahwa membuat standar operasional prosedur tentang pemeliharaan mesin produksi menjadi tindakan mendesak yang saat ini perlu dilakukan oleh PT. XYZ.
\end{abstract}

Kata Kunci : Produk cacat, peta kendali P, Root Cause Analysis.

\section{PENDAHULUAN}

Revolusi industri 4.0 memberi pengaruh pada kegiatan produksi industri, terutama dalam hal pengendalian mutu dan proses produksi secara efektif dan efisien. Produk cacat adalah unit produksi yang tidak memenuhi standar yang disyaratkan oleh pelanggan. Produk cacat dalam industri manufaktur dapat disebabkan oleh mesin, metode, material, manusia, pengukuran, lingkungan (Islam, Khan, et.al 20 13).Tingginya produk cacat yang dihasilkan menunjukkan ketidakefektifan dan ketidakefisienan dari produksi yang sedang berlangsung dan berdampak pada penurunan laba perusahaan.

Produk yang diproduksi oleh PT. XYZ salah satunya adalah wafer cigaro stick. Produksi wafer Cigaro mengalami peningkatan produk cacat (ditunjukkan pada Tabel 1), tentu ini menjadi kendala dan perhatian bagi manajemen perusahaan. Produk yang dihasilkan harus memiliki kualitas produk yang baik dan sesuai dengan standar.

Menanggapi masalah ini, PT. XYZ berusaha untuk melakukan pengendalian kualitas di 5 line produksi yang berjalan. Menurut Patil dan Sutar (2015), pengawasan adalah kegiatan yang 
dilakukan untuk memastikan bahwa sesuai dengan yang direncanakan. kegiatan produksi dan operasi dilakukan

Tabel 1. Data produk cacat bulan Januari - Juli 2017

\begin{tabular}{|c|c|c|c|c|c|}
\hline \multirow{2}{*}{ Bulan } & \multicolumn{5}{|c|}{ Jumlah produk cacat } \\
\cline { 2 - 6 } & Line 1 & Line 2 & Line 3 & Line 4 & Line 5 \\
\hline Jan-17 & 234 & 211 & 210 & 215 & 211 \\
\hline Feb-17 & 220 & 207 & 211 & 220 & 220 \\
\hline Mar-17 & 219 & 221 & 220 & 215 & 219 \\
\hline Apr-17 & 237 & 230 & 218 & 225 & 231 \\
\hline May-17 & 228 & 234 & 221 & 234 & 205 \\
\hline Jun-17 & 230 & 230 & 229 & 238 & 219 \\
\hline
\end{tabular}

Hasil pemeriksaan diperoleh informasi tentang perkembangan kualitas produk yang dibutuhkan oleh manajemen. Informasi yang diperoleh tidak hanya dalam bentuk informasi produk cacat tetapi juga memberikan informasi tentang jumlah produk cacat terbesar, penyebab, dan pengembangan kualitas produk untuk jangka waktu tertentu.

Proses pengendalian kualitas dilakukan melalui proses PDCA (plan, do, check, action) yang diperkenalkan oleh Dr. W. Edwards Deming, seorang ahli kualitas terkenal dengan kebangsaan Amerika, sehingga siklus ini disebut Deming Cycle. Siklus PDCA umumnya digunakan sebagai alat statistik utama, yaitu lembar periksa, histogram, diagram kontrol, diagram pareto, diagram sebabakibat, diagram pencar, dan stratifikasi (Mandavgade et al,. 2009).

Alat-alat ini berguna dalam mengumpulkan informasi yang obyektif untuk digunakan sebagai dasar untuk pengambilan keputusan. Menurut Muchsin (2015), Peta kendali $P$ digunakan sebagai metode grafik untuk mengevaluasi apakah proses produksi di PT. XYZ dalam pengendalian kualitas statistik atau tidak, sehingga dapat memecahkan masalah dan menghasilkan peningkatan kualitas.
Analisis rinci dari identifikasi kegiatan tidak ada nilai tambah dilakukan dengan menggunakan analisis penyebab akar yang dikenal sebagai RCA, menurut Jucan (2005) Root Cause Analysis adalah metodologi untuk mengidentifikasi dan memperbaiki penyebab fungsional. Metode RCA sangat berguna untuk menganalisis kegagalan sistem tentang hal-hal tak terduga yang terjadi, bagaimana itu bisa terjadi, dan mengapa itu bisa terjadi. Penelitian ini bertujuan untuk menganalisis produk cacat dan untuk mengidentifikasi apakah penyebab terjadinya serta memberikan saran untuk perbaikan sehingga jumlah produk cacat dapat dikurangi.

\section{METODOLOGI}

Keberhasilan penelitian ditentukan oleh langkah-langkah penelitian yang baik dan jelas, sehingga dapat dengan mudah dilihat langkah-langkah apa yang harus diambil untuk mencapai tujuan dan proses penelitian. Adapun metode dalam penelitian ini meliputi: Analisis awal, pengumpulan data, analisis pengendalian mutu menggunakan Peta Kendali P, dan analisis faktor-faktor yang menyebabkan produk cacat tinggi menggunakan RCA. Untuk informasi yang lebih jelas, lihat Gambar 1. 


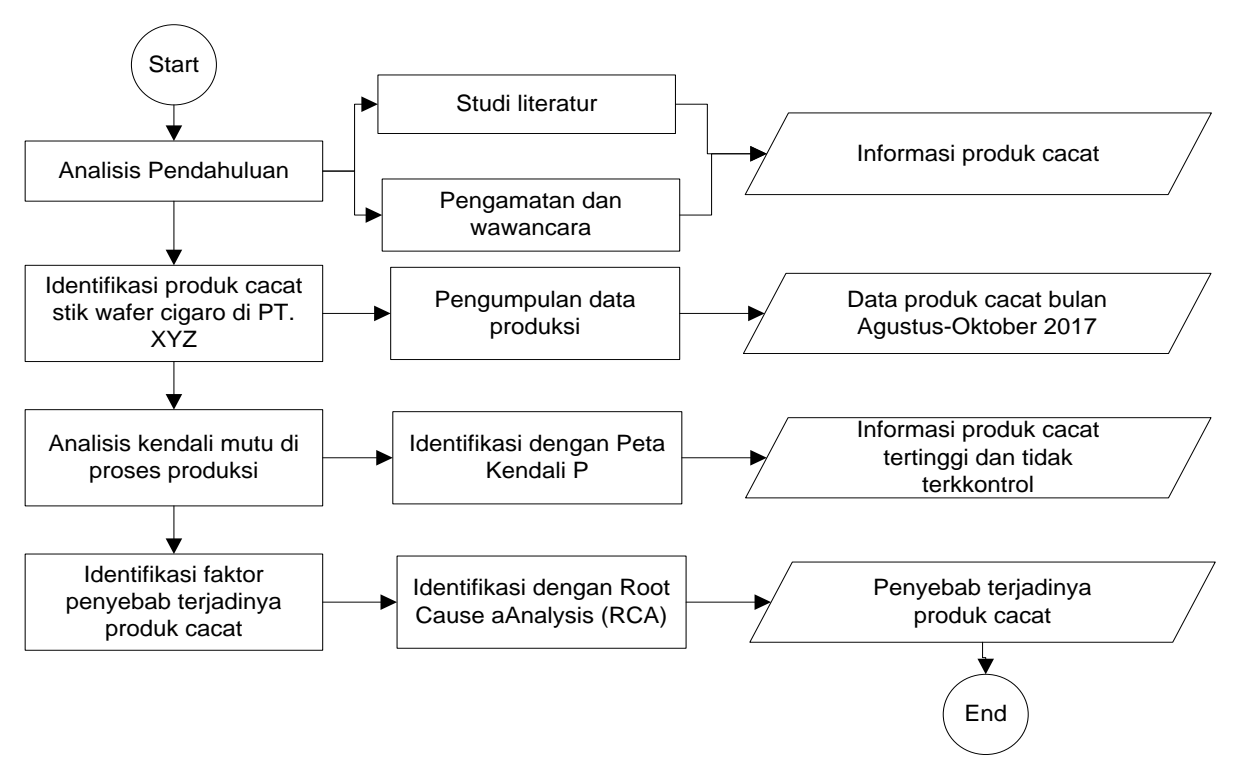

Gambar 1. Tahapan Penelitian

Analisis awal dilakukan dengan meninjau penelitian sebelumnya untuk mencari tahu penyebab produk cacat secara umum dan langkah minimasi. Terdapat 5 makalah penelitian diambil dari berbagai sumber untuk dijadikan referensi dalam pembahasan penelitian inimsetelah meninjau makalah dengan solusi dan manfaat yang mungkin yang disebutkan di bawah ini.

\section{Peta Kendali $P$}

Data diambil dari Agustus hingga Oktober 2017, pengumpulan data dilakukan dengan metode sampling dan 120 pcs produk/hari diambil untuk setiap sampling. Data yang telah dikumpulkan diolah menggunakan peta kendali $\mathrm{P}$ dengan menghitung nilai proporsi ditolak, standar deviasi, dan perhitungan batas kontrol.

2. Root Cause Analysis (RCA)

Analisis RCA digunakan untuk menganalisis faktor-faktor yang menyebabkan produk cacat dan langkah-langkah korektif atau saran yang dapat diterapkan dalam meminimalkan jumlah produk cacat dalam proses produksi. Dalam menganalisa penyebab menggunakan RCA ada 2 pendekatan yang dapat digunakan, yaitu 5-whys dan diagram fishbone. Langkah-langkah dalam RCA dilakukan dengan mendefinisikan masalah, menyelidiki akar penyebab masalah, rencana aksi, dan pemantauan.

\section{HASIL DAN PEMBAHASAN}

\section{Analisis Awal}

Data yang diolah merupakan data sekunder dari total produk cacat pada bulan Agustus - Oktober 2017 yang diperoleh dari bagian Pengendalian Mutu PT. XYZ. Data dapat dilihat pada Tabel 2 dan Gambar 2.

Dari data yang diperoleh pada bulan Agustus hingga Oktober 2017, produk cacat tertinggi diperoleh pada bulan Oktober line 2. Selanjutnya, data dianalisis menggunakan Peta Kendali P untuk mengetahui apakah data masih dalam kontrol atau tidak terkendali. 
Tabel 2. Data Produk Cacat pada Bulan Agustus - Oktober 2017

\begin{tabular}{|c|c|c|c|c|c|}
\hline \multirow{2}{*}{ Bulan } & \multicolumn{5}{|c|}{ Jumlah produk cacat } \\
\cline { 2 - 6 } & Line 1 & Line 2 & Line 3 & Line 4 & Line 5 \\
\hline August & 322 & 335 & 275 & 283 & 279 \\
\hline September & 304 & 338 & 270 & 249 & 232 \\
\hline October & 351 & $\mathbf{3 9 8}$ & 227 & 283 & 243 \\
\hline
\end{tabular}

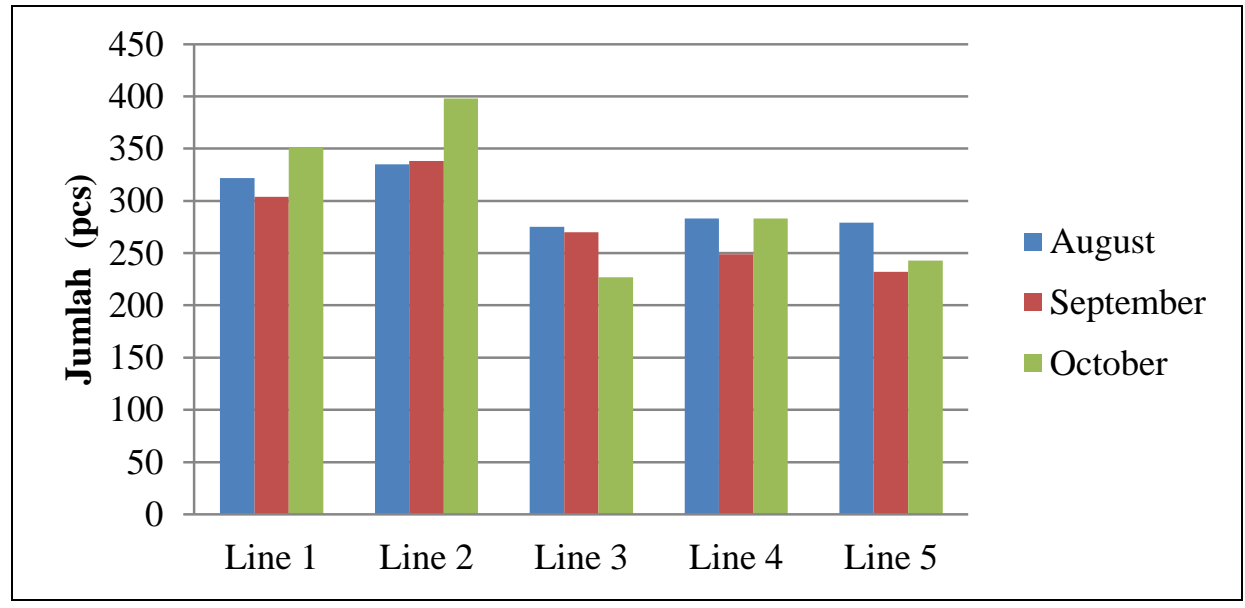

Gambar 2. Grafik Jumlah Produk Cacat

\section{Peta Kendali $\mathrm{P}$}

Peta kendali $\mathrm{P}$ digunakan untuk melihat batas kontrol atas dan batas kontrol yang lebih rendah. Jika data masih dalam batas kontrol, data dinyatakan terkontrol. Berikut ini adalah pengolahan data dengan metode peta kendali $\mathrm{P}$ line 2 pada bulan Oktober 2017. Peta kendali P digunakan untuk menghitung proporsi cacat dan persentase ditolak dalam Line 2 produksi pada bulan Oktober 2017. Hasil pengolahan data dapat dilihat pada Tabel 3.

$$
\text { Penyelesaian data sampling }
$$
dengan perhitungan Peta Kendali $P$ sebagai berikut :

$$
\begin{aligned}
& \text { Rata-rata atau } \bar{P}=\frac{\text { Jumlah produk cacat }}{\text { Jumlah pemeriksaan }} \\
& =\frac{3.32}{26} \\
& =0.13
\end{aligned}
$$

Std. deviasi

$$
\begin{aligned}
S_{p} & =\sqrt{\frac{\bar{p}(1-\bar{p})}{\bar{n}}} \\
& =\sqrt{\frac{0.13(1-0.13)}{120}} \\
& =0.03
\end{aligned}
$$

CL

$$
=0.13
$$

$\mathrm{UCL}=\overline{\mathrm{p}}+3 \mathrm{~S}_{\mathrm{p}}$

$$
=0.25
$$

$$
\begin{aligned}
\mathrm{LCL} & =\overline{\mathrm{p}}-3 \mathrm{~S}_{\mathrm{p}} \\
& =0.13-3(0.03) \\
& =0.01
\end{aligned}
$$


Tabel 3. Data Sampling Produk Cacat pada Bulan Oktober 2017 di Line 2

\begin{tabular}{|c|c|c|c|c|c|}
\hline No & Tanggal & Jumlah Sampling & Produk cacat & Proporsi cacat & Presentase cacat \\
\hline 1 & 2 & 120 & 19 & 0.16 & 15.83 \\
\hline 2 & 3 & 120 & 20 & 0.17 & 16.67 \\
\hline 3 & 4 & 120 & 20 & 0.17 & 16.67 \\
\hline 4 & 5 & 120 & 11 & 0.09 & 9.17 \\
\hline 5 & 6 & 120 & 23 & 0.19 & 19.17 \\
\hline 6 & 7 & 120 & 22 & 0.18 & 18.33 \\
\hline 7 & 9 & 120 & 10 & 0.08 & 8.33 \\
\hline 8 & 10 & 120 & 12 & 0.10 & 10.00 \\
\hline 9 & 11 & 120 & 11 & 0.09 & 9.17 \\
\hline 10 & 12 & 120 & 15 & 0.13 & 12.50 \\
\hline 11 & 13 & 120 & 16 & 0.13 & 13.33 \\
\hline 12 & 14 & 120 & 10 & 0.08 & 8.33 \\
\hline 13 & 16 & 120 & 13 & 0.11 & 10.83 \\
\hline 14 & 17 & 120 & 15 & 0.13 & 12.50 \\
\hline 15 & 18 & 120 & 20 & 0.17 & 16.67 \\
\hline 16 & 19 & 120 & 20 & 0.17 & 16.67 \\
\hline 17 & 20 & 120 & 19 & 0.16 & 15.83 \\
\hline 18 & 21 & 120 & 9 & 0.08 & 7.50 \\
\hline 19 & 23 & 120 & 11 & 0.09 & 9.17 \\
\hline 20 & 24 & 120 & 16 & 0.13 & 13.33 \\
\hline 21 & 25 & 120 & 19 & 0.16 & 15.83 \\
\hline 22 & 26 & 120 & 20 & 0.17 & 16.67 \\
\hline 23 & 27 & 120 & 7 & 0.06 & 5.83 \\
\hline 24 & 28 & 120 & 9 & 0.08 & 7.50 \\
\hline 25 & 30 & 120 & 11 & 0.09 & 9.17 \\
\hline 26 & 31 & 120 & 20 & 0.17 & 16.67 \\
\hline Jumlah & $\mathbf{3 1 2 0}$ & $\mathbf{3 9 8}$ & $\mathbf{3 . 3 2}$ & $\mathbf{3 3 1 . 6 7}$ \\
\hline & & & & & \\
\hline
\end{tabular}

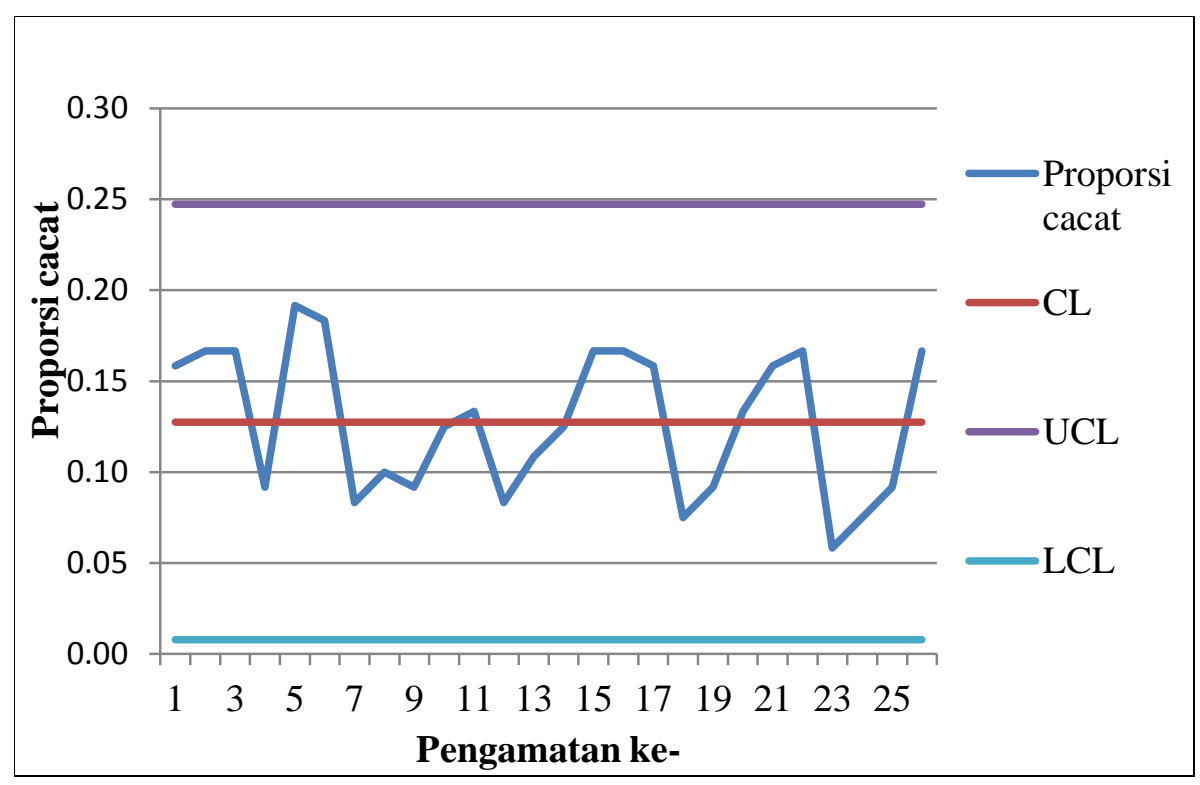

Gambar 3. Grafik peta kendali P pada Line 2 bulan Oktober 2017 
Dari pengolahan data di atas, dinyatakan bahwa data produk cacat dari Agustus hingga Oktober 2017 terkendali atau tidak ada data yang keluar dari batas atas dan bawah. Pengolahan data hanya dilakukan pada mesin dan line dengan produk cacat tertinggi, yaitu pada line 2 bulan Oktober 2017
3. Root Cause Analysis (RCA)

Analisis dilakukan berdasarkan data yang diperoleh, analisis dilakukan menggunakan metode analisis akar penyebab pendekatan fishbone diagram untuk menganalisis penyebab tingginya produk cacat pada produksi wafer cigaro yang PT. XYZ. Dapat dilihat pada Gambar 4.

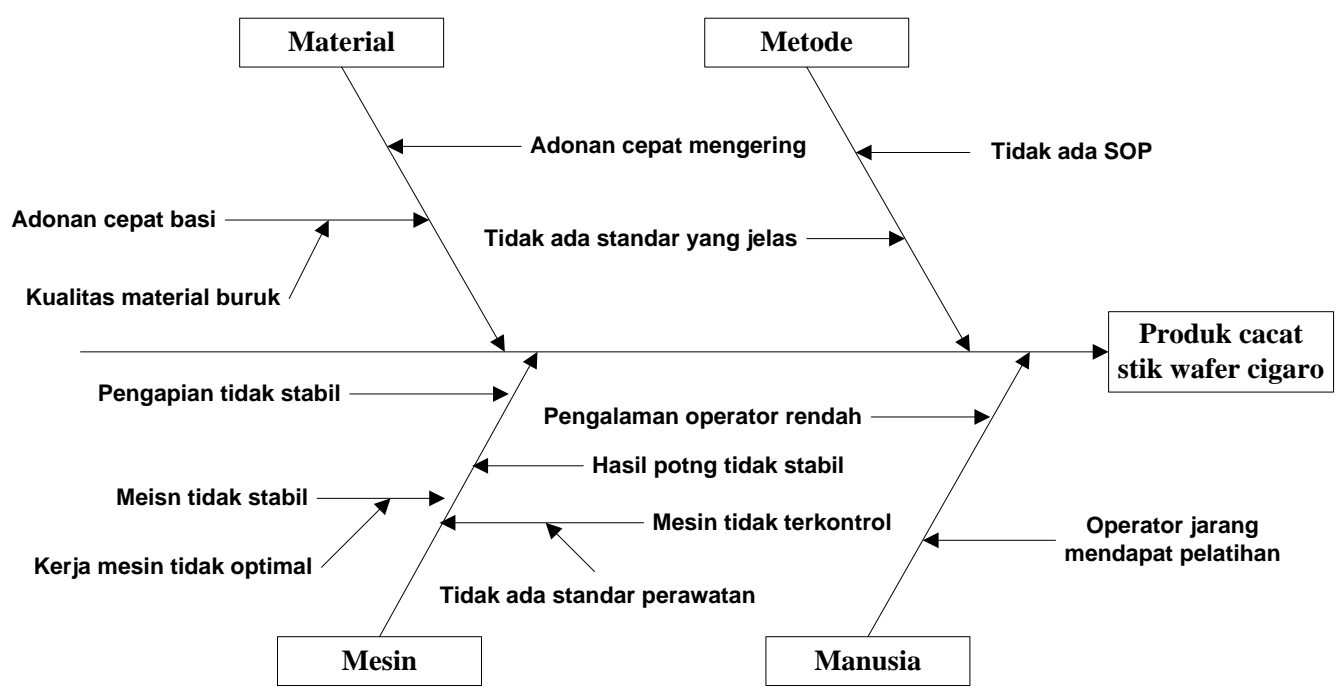

Gambar 4. Diagram Fishbone produk cacat di PT. XYZ

a. Bahan baku : Bahan yang digunakan untuk produksi wafer stik cigaro terdiri dari: tepung, gula, air, minyak, bubuk coklat, dan tambahan makanan. Bahan mentah menggunakan tambahan air sehingga ada sedimen dan adonan cepat mengeras jika ada waktu tunggu produksi yang lama.

b. Metode : Tidak ada standar proses produksi. Standar produk masih sering berdasarkan asumsi menurut pendapat seorang manajer atau yang lain.

c. Manusia : Operator menjalankan mesin sembarangan atau dengan prinsip "biasanya seperti ini". Operator jarang mendapatkan pelatihan tentang cara mengoperasikan mesin dengan baik dan benar.

d. Mesin : Kondisi mesin yang lama menyebabkan mesin berjalan tidak stabil. Jadi ada banyak produk cacat ditambah dengan tidak adanya SOP pemeliharaan mesin sehingga kondisi tidak terjaga. Kondisi yang sangat penting untuk diperbaiki atau dilakukan adalah perawatan pada pengapian yang tidak stabil dan sensor pemotongan yang sudah mulai rusak, menyebabkan banyak produk yang ditolak muncul.

Berdasarkan hasil analisa dengan fishbone maka dilakukan wawancara dengan beberapa pihak produksi terkait kendala yang menyebabkan terjadinya produk cacat dengan pendekatan 5-whys 
yang kemudian akan menjadi acuan wawancara kendala produksi dapat saran atau perbaikan yang akan dilihat pada Tabel 4.

dilaksanakan oleh PT. XYZ. Tabel

\section{Tabel 4. Hasil Wawancara Kendala Produksi}

\begin{tabular}{|c|c|c|}
\hline \multicolumn{2}{|r|}{ Produk cacat stik wafer cigaro } & \multirow[t]{2}{*}{ Total jawaban } \\
\hline Mengapa 1 & & \\
\hline \multicolumn{3}{|c|}{ Jumlah produk cacat } \\
\hline \multirow{5}{*}{ Penyebab } & Mesin tidak layak & 1 \\
\hline & Mesin using & 2 \\
\hline & Adonan basi & 4 \\
\hline & Mesin harus diatur ulang saat dimatikan & 1 \\
\hline & Mesin jarang dirawat & 2 \\
\hline \multicolumn{3}{|c|}{ Adonan basi } \\
\hline \multicolumn{3}{|l|}{ Mengapa 2} \\
\hline \multirow{5}{*}{ Penyebab } & Mesin sering restart & 1 \\
\hline & Kualitas bahan baku tidak baik & 1 \\
\hline & Mesin tidak stabil & 6 \\
\hline & Mesin sering error & 1 \\
\hline & Penumpukan adonan dalam mesin & 1 \\
\hline \multicolumn{3}{|c|}{ Mesin tidak stabil } \\
\hline \multicolumn{3}{|c|}{\begin{tabular}{l|l} 
Mengapa 3 & \\
\end{tabular}} \\
\hline \multirow{5}{*}{ Penyebab } & Operator baru & 1 \\
\hline & Sensor memotong acak & 5 \\
\hline & Operator tidak kompeten & 2 \\
\hline & Pemotongan sensor jarang dibersihkan & 1 \\
\hline & Hidangan tidak stabil & 1 \\
\hline \multicolumn{3}{|c|}{ Sensor memotong acak } \\
\hline \multicolumn{3}{|l|}{ Mengapa 4} \\
\hline \multirow{5}{*}{ Penyebab } & Kabel sensor hampir putus & 1 \\
\hline & Mesin jarang diperbaiki & 6 \\
\hline & Pemegang sensor tidak cocok & 2 \\
\hline & Kesalahan sensor & 2 \\
\hline & Komponen sensor rusak & 1 \\
\hline \multicolumn{3}{|c|}{ Mesin jarang diperbaiki } \\
\hline \multicolumn{3}{|l|}{ Mengapa 5} \\
\hline \multirow{5}{*}{ Penyebab } & Operator tidak loyal & 2 \\
\hline & Tidak ada standar perawatan & 4 \\
\hline & Tidak ada perawatan mesin & 2 \\
\hline & Tidak ada operator yang mengarah & 1 \\
\hline & Tidak ada jadwal perawatan & 1 \\
\hline \multicolumn{2}{|c|}{ Tidak ada SOP pemeliharaan mesin } & \\
\hline
\end{tabular}

Dari hasil analisis wawancara kendala produksi, metode 5-whys diringkas dari pertanyaan-pertanyaan yang telah diajukan dari operator kepada manajer produksi dan diperoleh data seperti yang disajikan pada Gambar 5 . 


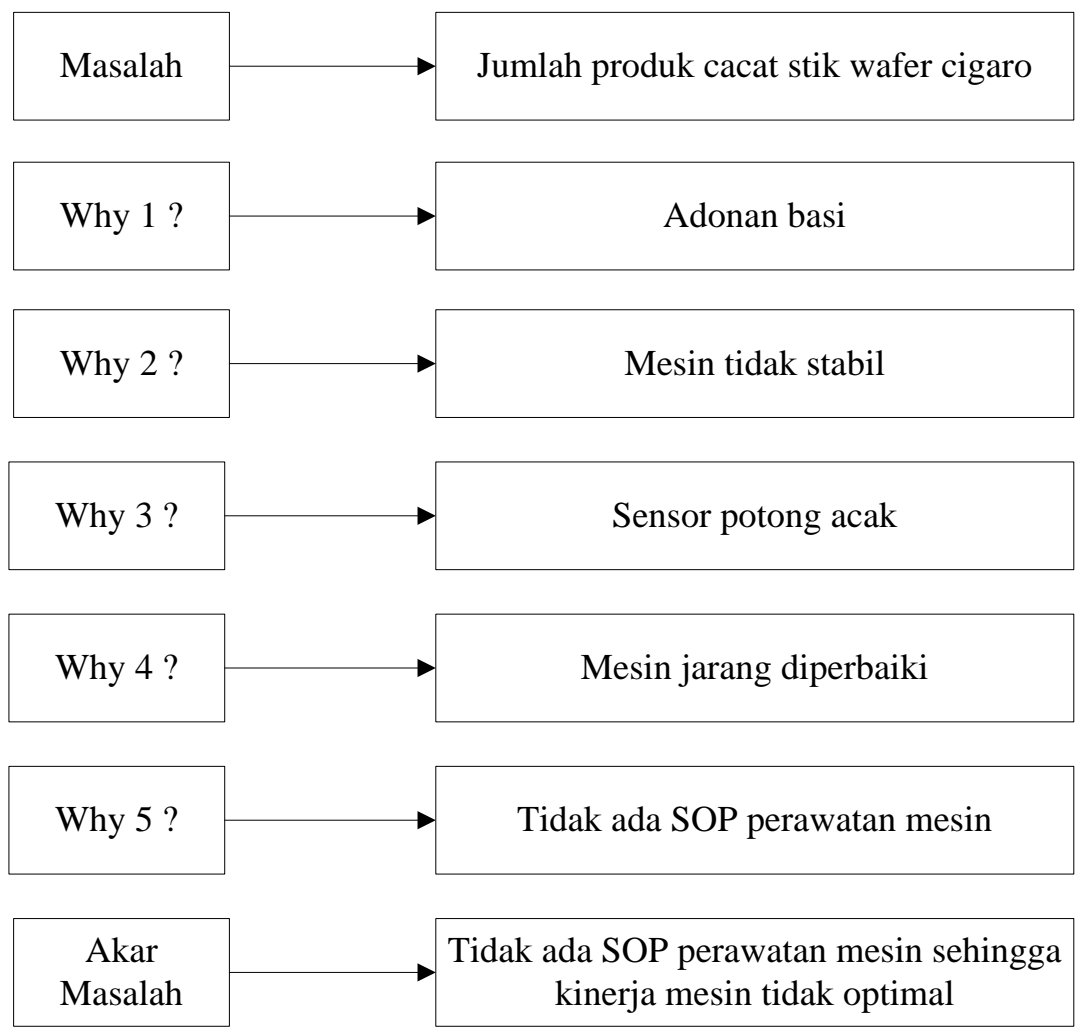

Gambar 5. Analisis 5-whys Produk Cacat

Adonan basi yang dijalankan di mesin perlu disetel ulang, karena campuran basi memiliki karakter yang berbeda dari campuran segar. Menjalankan mesin dengan adonan basi akan membuat mesin tidak stabil dan sering terjadi cacat. Ini juga mempengaruhi sensor pemotongan yang acak karena ketebalan campuran tidak rata, ditambah kondisi mesin jarang diperbaiki karena tidak ada jadwal perawatan untuk mesin sehingga perbaikan mesin dilakukan saat mesin tidak lagi bisa beroperasi. SOP untuk perawatan mesin diperlukan untuk mendukung kelancaran proses pembuatan stik wafer cigaro di semua line.

\section{KESIMPULAN}

Dari tinjauan artikel penelitian yang disebutkan di atas, diperoleh kesimpulan berikut: a. Proporsi produk cacat dari Line 1-5 pada Agustus 2017 hingga Oktober 2017 masih dapat dikendalikan.

b. PT. XYZ harus mendesain SOP proses produksi, terutama di bagian perawatan mesin sehingga dapat menekan jumlah produk cacat

c. SOP standar pemeliharaan mesin adalah hal yang paling penting yang harus segera dilakukan oleh PT. XYZ .

\section{DAFTAR PUSTAKA}

Islam, M., Khan, A. M., \& Khan, M. R. (2013). Minimization of Defects in the Sewing Section of Apparel Industry, 2(8), 10-15.

Jucan. 2005. Pendekatan Lean Thinking dengan menggunakan metode Root Cause Analysis untuk mengurangi non value added activities. J. Pasti. 8(2): 236-250. 
Mandavgade, N. K., \& Jaju, S. B. Patil, V., \& Sutar, M. (2015). Quality (2009). Optimization of Cost by Using 7 QC Tools, 1(3), 149-160.

Muchsin. 2015. Aplikasi peta kendali P dalam praktikum kendali mutu. J. Mekanika. 3(2): 608-614. control and Statistical Techniques used to improve Productivity and to reduce Rejections due to Casting Defects : A Review, 3(4), 71-78. 